\title{
RESEARCH PAPER \\ Effect of bokashi and vermicompost leachate on yield and quality of pepper (Capsicum annuum) and onion (Allium cepa) under monoculture and intercropping cultures
}

\author{
José D. Álvarez-Solís ${ }^{1}$, José A. Mendoza-Núñez ${ }^{1}$, Noe S. León-Martínez, \\ Jorge Castellanos-Albores ${ }^{1}$ and Federico A. Gutiérrez-Miceli ${ }^{2}$ \\ ${ }^{1}$ El Colegio de la Frontera Sur (ECOSUR), Carretera Panamericana y Periférico Sur (s/n), C.P. 29290, San \\ Cristóbal de Las Casas, Chiapas, Mexico. \\ ${ }^{2}$ Instituto Tecnológico de Tuxtla Gutiérrez, Carretera Panamericana km 1080, Tuxtla Gutiérrez, Chiapas, \\ Mexico.
}

\begin{abstract}
J.D. Álvarez-Solís, J.A. Mendoza-Núñez, N.S. León-Martínez, J. Castellanos-Albores, and F.A. Gutiérrez-Miceli. 2016. Effect of bokashi and vermicompost leachate on yield and quality of pepper (Capsicum annuum) and onion (Allium cepa) under monoculture and intercropping cultures. Cien. Inv. Agr. 43(2):243-252. Organic fertilization and crop association are two agroecological management practices that have the potential to optimize land use in horticultural production. The objective of this study was to evaluate the effect of Bokashi and Bokashi amended with Vermicompost Leachate (VL) on the growth, yield and quality of jalapeño pepper (Capsicum annuum L.) and onion (Allium cepa L.) in monoculture and intercropping cultures. This work was conducted under rainfed conditions in the community of Santa Rosa el Oriente, a municipality of Trinity, Chiapas. A randomized complete block design in a split plot arrangement with six treatments and four replicates by treatment was used. Bokashi significantly increased the number of leaves and plant height in onion (37 and 62\%) and jalapeño pepper (133 and 94\%) compared with the control plants. In jalapeño pepper and onion, the content of capsaicin and soluble solids was 41 and $42 \%$ higher with the application of Bokashi plus VL, respectively. In onion, Bokashi increased the polar and equatorial diameters and bulb weight by 28, 69 and 269\%, respectively, and its yield increased from 6.4 to $21.0 \mathrm{t}$ $\mathrm{ha}^{-1}$. The land equivalent ratio (LER) was 1.34 to 1.55 , which indicated that intercropping was advantageous on monoculture, regardless of the fertilization type. Therefore, the application of Bokashi and crop association favored the yield and quality of jalapeño pepper and onion with an efficient use of the land.
\end{abstract}

Key words: Bokashi, capsaicin, land equivalent ratio, soluble solids, vermicompost leachate.

\section{Introduction}

On an international level, small farmers accomplish their agricultural, livestock and forestry activi-

Received November 28, 2015. Accepted June 30, 2016. Corresponding author: dalvarez@ecosur.mx ties with very scarce land and capital resources, which results in small landholdings and extreme poverty. It has been estimated that approximately 1.4 billion people depend on conducting agricultural work under rainfed conditions, with several environmental and economic limitations and 
without access to modern agricultural technology (Altieri, 2002). The use of industrial fertilizers in agricultural production is expensive for small farmers; most cannot buy such fertilizers. Furthermore, there has been serious concern about the long-term adverse effects of the intensive use of chemical fertilizers on both soil health and the environment (van Diepeningen et al., 2006). A new approach to natural resource management must be developed so agricultural systems can be built and adapted in a site-specific way according to the conditions of small farmers (Altieri, 2002). In this work, we considered two relevant agroecological management practices: the use of local organic fertilizers to maintain soil fertility and plant nutrition, and crop association to optimize land use. Jalapeño pepper (Capsicum annuum L.) and onion (Allium cepa L.) are two important crops for family food security and for sale in local market. Capsaicin in jalapeño peppers and piruvic acid in onions are related to the pungency of the vegetables and provide important antioxidants for the human diet (Teare-Ketter and Randle, 1998; Váquez-Flota et al., 2007).

There are different methods for producing organic fertilizers by processing the organic residues that result from agricultural activity. The composting process, such as Bokashi, is a biological aerobic transformation of organic residues with energy sources (such as molasses) that accelerate the oxidation of organic matter through a thermophilic phase $\left(45\right.$ to $\left.65^{\circ} \mathrm{C}\right)$ in which microorganisms liberate heat, carbon dioxide and water, thus permitting the obtainment of a product in a short period of time. The vermicomposting does not include a thermophilic phase, but involves the use of earthworms for breaking down and stabilizing the organic wastes (Atiyeh et al., 2000). In the vermicomposting process, beds filled with composted waste, earthworms and bedding material are fitted with a drainage and collection system. Leachate obtained as effluent from vermiculture beds, which is often called Vermicompost Leachate (VL), can be used as a liquid fertilizer (García-Gómez et al., 2008;
Oliva-Llaven et al., 2010). It has been shown that organic fertilizers, such as Manure, Compost, Bokashi and VL, improve the soil organic matter and nutrient availability (Sinaj et al., 2002) and increase the microbial biomass, soil enzyme activity (Acosta and Paolini, 2005), and number and diversity of soil bacteria (van Diepeningen et al., 2006). Its positive effects on soil quality are reflected in better nutrition and crop yields and could modify the organoleptic characteristics of fruits due to an increase in organic substances (Gutiérrez-Miceli et al., 2007; Oliva-Llaven et al., 2008). However, the amount of organic fertilizer that must be applied varies between crops and depends on the availability of resources which has the small farmer for processing. Therefore, it is necessary to test different complementation alternatives to determine which meet the nutritional requirements of plants. One option is to combine soil with foliar organic fertilization.

Intercropping is the mixed growth of two or more crops in the same field. This practice reduces the risk of total loss, improves the use of resources, provides protection against pests and diseases, and provides stability and the proper administration of work throughout the year (Vandermeer, 1990; Malézieux et al., 2009). One way to determine the benefit or limitation of intercropping is by measuring the unit or land equivalent ratio (LER), defined as the area of land under monoculture that is needed to obtain the same production in intercropping (Willey and Rao, 1980; Dariush et al., 2006). The benefits of intercropping are a reason to evaluate spatial and temporal designs in horticultural crops that act in synergy between the components of biodiversity above and underground, which are key factors that influence ecological processes such as nutrient cycling and productivity (Altieri and Nicholls, 2007). The integration of organic fertilization and crops association with agroecological management could to improve production with fewer external inputs and without negative environmental impacts (Altieri, 2002). The aim of this study was to evaluate the effect of Bokashi and VL as organic fertilizers and to 
determine the crop association on the growth, yield and quality of jalapeño peppers (C. annuиm) and onion (A. cepa L.) under rainfed conditions in Santa Rosa el Oriente, Chiapas.

\section{Material and methods}

This study was conducted in the community of Santa Rosa el Oriente, a municipality of Trinity, Chiapas, México, located at 91 $40^{\prime} 27^{\prime \prime}$ $\mathrm{N}$ and $16^{\circ} 08^{\prime} 10^{\prime \prime} \mathrm{O}$, at $1407 \mathrm{~m}$ above sea level. This community is inhabited by 55 families of the Maya Chuj ethnic group. The land surface for each family is $3,750 \mathrm{~m}^{2}$, of which $3,125 \mathrm{~m}^{2}$ is occupied by maize and bean production and the rest by the home garden. The predominant climate is temperate humid, with rain year-round and an average annual temperature of $16-18^{\circ} \mathrm{C}$, without the risk of frost in the colder months. The average annual rainfall is $1,840 \mathrm{~mm}$, peaking in August-November (1,200 to $1,400 \mathrm{~mm})$ (Ramírez-Marcial et al., 2010). The soil is a Rendzic Leptosol and is shallow stony, shallow and steep, with high levels of organic matter (6.6\%) and total N (0.45\%); it is low in P-Olsen $\left(2.2 \mathrm{mg} \mathrm{kg}^{-1}\right)$, its $\mathrm{pH}$ is slightly acidic (6.6) and it has high CEC (28.8 $\left.\mathrm{Cmol} \mathrm{kg}^{-1}\right)$.

The experiment was established with the participation of a group of small farmers interested in the organic production of onion and jalapeño pepper in a plot that had been used for maize cultivation. Six treatments were evaluated: 1) Monoculture without fertilizer; 2) Monoculture fertilized with Bokashi; 3) Monoculture fertilized with Bokashi plus Vermicompost Leachate (VL); 4) Intercropping without fertilizer; 5) Intercropping fertilized with Bokashi; and 6) Intercropping fertilized with Bokashi plus VL. The experimental design consisted of split plots and randomized blocks with four replications. The main plot corresponded to the type of fertilizer (Bokashi, Bokashi plus VL, and control without fertilizer), and a small plot was assigned to the crop association of jalapeño pepper and onion (monoculture and intercropping). The experimental units had an area of $2.25 \mathrm{~m}^{2}$. A substitution model was used in intercropping (García, 2003), where $40 \%$ of the plants in the onion monocrop were substituted by jalapeño pepper plants. The seeds of the plants were obtained in the local market, sown in a seedbed and held for 62 days. In transplantation, the plant spacing was $15 \times 30 \mathrm{~cm}$ for onion and $30 \times 45 \mathrm{~cm}$ for jalapeño pepper. Bokashi was applied upon transplanting at $10 \mathrm{~cm}$ deep with a dose of $10 \mathrm{~kg}$ $\mathrm{m}^{-2}$. VL was applied as a foliar fertilizer at up to $10 \%$ every $10 \mathrm{~d}$ since $22 \mathrm{~d}$ after transplanting (DAT) at four different times.

Bokashi was prepared through an aerobic fermentation process for 30 days with the following materials: sheep, chicken and cow manures, corn stalks, straw, green grass, green leaves and forest soil, which was added with yeast and molasses. VL was obtained from a vermiculture bed with cow manure and earthworm (Eisenia fetida) (García-Gómez et al., 2008). Before transplanting and fertilizer application, a soil sample from a 20 -cm depth was collected. Organic fertilizers and soil were processed and analyzed using the techniques described in the Mexican Official Norm (2002); Nitrogen (N) was determined by the micro-Kjeldahl technique and Phosphorous (P) by the Olsen method (using $\mathrm{NaHCO}_{3} 0.5$ $\mathrm{M}, \mathrm{pH}$ 8.5). Macronutrients ( $\mathrm{K}, \mathrm{Ca}, \mathrm{Mg}, \mathrm{Na}$ ) and micronutrients $(\mathrm{Cu}, \mathrm{Fe}, \mathrm{Mn}$ and $\mathrm{Zn})$ were extracted with acetate of ammonium $1 \mathrm{~N}, \mathrm{pH} 7$ in soil, and with a solution of nitric acid-perchloric acid $\left(\mathrm{HNO}_{3}-\mathrm{HClO}_{4}\right)$ in Bokashi. $\mathrm{Ca}, \mathrm{Mg}$ and extractable micronutrients were determined by atomic absorption spectrophotometry, and $\mathrm{K}$ and $\mathrm{Na}$ were detected by flame emission spectroscopy. The chemical characteristics that were determined are shown in Table 1. For disease control, an application of Bordeaux mixture (1\% at 14 DAT) was performed because the jalapeño pepper developed symptoms of basal stem rot (Phytophthora spp.) and wide stem (Fusarium spp.). A second application was made at 30 DAT (Restrepo, 2007). 
Table 1. Nutrient content $\left(\mathrm{mg} \mathrm{kg}^{-1}\right)$ in the experimental soil, Bokashi and vermicompost leachate (VL).

\begin{tabular}{lcccccccccc}
\hline & $\mathrm{N}$ & $\mathrm{P}$ & $\mathrm{K}$ & $\mathrm{Ca}$ & $\mathrm{Mg}$ & $\mathrm{Na}$ & $\mathrm{Cu}$ & $\mathrm{Fe}$ & $\mathrm{Mn}$ & $\mathrm{Zn}$ \\
\hline Soil & 4500.0 & 2.2 & 97.8 & 2186.0 & 611.2 & 96.6 & 1.6 & 34.6 & 20.6 & 1.2 \\
Bokashi & 9500.0 & 105.8 & 4844.5 & 18538.0 & 8431.4 & 1971.1 & 224.9 & 234.8 & 3038.2 & 137.7 \\
VL & 236.0 & 3.2 & 39.4 & 52.9 & 164.0 & 405.2 & 13.8 & 12.6 & 10.9 & 51.6 \\
\hline
\end{tabular}

To assess the effect of treatments on plant growth, plant height was measured, and the number of leaves was counted at 33 DAT. Additionally, the fresh and dry weights of foliage (oven dried for 48 $\mathrm{h}$ at $65^{\circ} \mathrm{C}$ ) were measured at 63 DAT. At harvest time, the length and diameter of jalapeño pepper were measured, as were the polar and equatorial diameters of the onion. The yield of jalapeño pepper was measured considering 4 cuts; fruit weight was assessed according to the Mexican Official Norms for onion (2003) and jalapeño pepper (2007). The soluble solids content in onion bulbs and jalapeño fruit was determined using a refractometer (Abbe 2WAJ) in degrees Brix, according to the method of AOAC (1990). To estimate the effect that the treatments had on pungency in onion and jalapeño pepper, pyruvic acid and capsaicin concentration were determined according to the methods proposed by Teare-Ketter and Randle (1998) and García et al. (2006), respectively. The onion bulbs and jalapeño pepper fruits from each treatment were cut into small slices and pooled. For the determination of piruvic acid, $20 \mathrm{~g}$ of a fresh sample was mixed and homogenized with $20 \mathrm{~mL}$ of deionized water for $10 \mathrm{~min}$; $0.5 \mathrm{~mL}$ of a homogenized sample was mixed with $1.5 \mathrm{~mL}$ of trichloroacetic acid (5\%) and allowed to sit for $1 \mathrm{hr}$, and $18 \mathrm{~mL}$ of deionized water was added. Then, $1 \mathrm{~mL}$ of this solution was mixed with $1 \mathrm{~mL}$ of 2,4-dinitrophenylhydrazine $(0.0125 \%)$ and 1 $\mathrm{mL}$ of deionized water, the mixture was incubated at $37^{\circ} \mathrm{C}$ for $10 \mathrm{~min}$, and $5 \mathrm{~mL}$ of $\mathrm{NaOH}(0.6 \mathrm{~N})$ was added. The reading was accomplished using a spectrophotometer (Varian Spectr AA220) to $420 \mathrm{~nm}$, with sodium pyruvate serving as the standard to obtain the standard curve (TeareKetter and Randle, 1998). For the determination of capsaicin, $5 \mathrm{~g}$ of a fresh sample was mixed and homogenized with $5 \mathrm{~mL}$ of ethanol, agitated for 15 min, and then filtered with ethanol until it reached a volume of $10 \mathrm{~mL}$. An aliquot of $2 \mathrm{~mL}$ was put on a separation funnel, and $3 \mathrm{~mL}$ of a solution buffer $\mathrm{pH}=3,10 \mathrm{~mL}$ of distilled water and 10 $\mathrm{mL}$ of Adogen-Tolueno were added. The mixture was agitated and allowed to rest until two phases appeared. The organic phase was recovered, and the concentration of capsaicin was estimated with a spectrophotometer (Varian Spectr AA220) at $286 \mathrm{~nm}$, using capsaicin to obtain the standard curve (0-0.5 $\left.\mathrm{mg} \mathrm{mL}^{-1}\right)$ (García et al., 2006).

The LER was calculated using the formula LER = $\sum$ (Ypi/Ymi), where Yp is the yield of each crop in the intercrop and $\mathrm{Ym}$ is the yield of each crop in the monoculture (Dariush et al., 2006). For each crop, (i) a ratio was calculated to determine the partial LER, and partial LERs were summed to give the total LER for the intercrop. When LER > 1 , intercropping is advantageous over monoculture; when LER $=1$, the planting mode does not matter; and when LER $<1$, monoculture is advantageous over intercropping (Willey and Rao, 1980).

\section{Statistical analysis}

The data were analyzed using analysis of variance (ANOVA) for a split plot design and a Tukey test to compare the means $(\mathrm{P} \leq 0.05)$. All analyses were performed using the SPSS v15 program. 


\section{Results and discussion}

\section{Growth and plant biomass}

The height and number of leaves in onion and jalapeño varied significantly $(\mathrm{P} \leq 0.05)$ between treatments, with higher values found for the application of Bokashi and Bokashi plus VL compared to plants without fertilizer. Intercropping had no significant effect on these variables of growth. and no significant interaction between factors was found (Table 2). Onion plants that were fertilized with Bokashi and Bokashi plus VL showed average increases of 37 and $27 \%$ in the number of leaves and increases of 62 and $46 \%$ in height relative to the control without fertilizer, whereas the jalapeño pepper exhibited increases of 111 and $129 \%$ in the number of leaves and of 94 and $84 \%$ in plant height. These results show that there was a greater response to organic fertilization in jalapeño pepper than in onion and that Bokashi plus VL application did not exceed the growth obtained with Bokashi.

The fresh and dry weight of foliage in the jalapeño and onion varied significantly $(\mathrm{P} \leq 0.05)$ between fertilization treatments. Neither crop association nor interaction with fertilization had no significant influence (Table 2). Applying Bokashi promoted greater fresh and dry weight of foliage, with average increases of 421 and $214 \%$ in jalapeno and 262 and $157 \%$ in onion compared to the control. In both cases, there was no significant difference between Bokashi application and Bokashi plus VL. The positive effect of organic fertilizers on plant growth has been attributed to its ability to supply minerals (Castro et al., 2009; Álvarez-Solís et al., 2010) and the variety of organic compounds that it contains (Gutiérrez-Miceli et al., 2007; OlivaLlaven et al., 2008). Nitrogen in organic fertilizer is mainly in organic form, and its availability varies depending on its concentration and $\mathrm{C} / \mathrm{N}$ ratio, which in turn depend on the materials used in the fertilizer's manufacture and maturity. In this work, Bokashi had a high content of total $\mathrm{N}$ $(0.95 \%)$ and a low $\mathrm{C} / \mathrm{N}$ ratio (9.6), which favors nutrient availability. In addition, it is important to consider the content of macro- and micro-nutrients that were provided by Bokashi (Table 1), which may explain why there was no response to the foliar application of VL.

\section{Physical and organoleptic characteristics of plants}

Neither applying Bokashi alone or in combination with VL nor the crops association had a significant effect on the size or fresh weight of jalapeño pepper fruit (Table 3). According to the Mexican Official Norm (2007), the length $(3.0-4.9 \mathrm{~cm})$, width $(2.5-2.9 \mathrm{~cm})$ and weight $(<$ $15.0 \mathrm{~g}$ ) of the harvested peppers could be classified as a short size, but with regard to quality, they were found to possess an extra degree of quality: they were free of physiological, me-

Table 2. Growth and biomass in jalapeño pepper and onion plants cultivated in monoculture and intercropping using Bokashi and vermicompost leachate (VL) as organic fertilizers.

\begin{tabular}{|c|c|c|c|c|c|c|c|c|}
\hline \multirow[b]{3}{*}{ Factors } & \multirow{2}{*}{\multicolumn{2}{|c|}{ Height $(\mathrm{cm})$}} & \multirow{2}{*}{\multicolumn{2}{|c|}{ Number of Leaves }} & \multicolumn{4}{|c|}{ Foliage weight $\left(\mathrm{g}\right.$ plant $\left.{ }^{-1}\right)$} \\
\hline & & & & & \multicolumn{2}{|c|}{ Fresh } & \multicolumn{2}{|c|}{ Dry } \\
\hline & Pepper & Onion & Pepper & Onion & Pepper & Onion & Pepper & Onion \\
\hline \multicolumn{9}{|l|}{ Culture type } \\
\hline Monoculture & $17.0 \pm 5.8 \mathrm{a}^{1}$ & $40.8 \pm 10.8 \mathrm{a}$ & $54.4 \pm 28.6 \mathrm{a}$ & $6.1 \pm 1.0 \mathrm{a}$ & $8.7 \pm 7.2 \mathrm{a}$ & $18.6 \pm 14.7 \mathrm{a}$ & $1.9 \pm 1.4 \mathrm{a}$ & $1.3 \pm 0.9 \mathrm{a}$ \\
\hline Intercropping & $16.2 \pm 5.2 \mathrm{a}$ & $42.0 \pm 10.6 \mathrm{a}$ & $42.4 \pm 16.2 \mathrm{a}$ & $6.3 \pm 1.3 \mathrm{a}$ & $5.3 \pm 3.9 \mathrm{a}$ & $24.0 \pm 14.4 \mathrm{a}$ & $1.4 \pm 1.7 \mathrm{a}$ & $1.6 \pm 0.9 \mathrm{a}$ \\
\hline \multicolumn{9}{|l|}{ Fertilization } \\
\hline Bokashi & $20.2 \pm 3.1 \mathrm{a}$ & $49.4 \pm 5.1 \mathrm{a}$ & $56.7 \pm 26.2 \mathrm{a}$ & $7.0 \pm 0.8 \mathrm{a}$ & $9.9 \pm 5.8 \mathrm{a}$ & $28.6 \pm 14.7 \mathrm{a}$ & $2.2 \pm 1.1 \mathrm{a}$ & $1.8 \pm 0.9 \mathrm{a}$ \\
\hline Bokashi $+\mathrm{VL}$ & $19.1 \pm 4.0 \mathrm{a}$ & $44.4 \pm 8.5 \mathrm{a}$ & $61.5 \pm 14.6 \mathrm{a}$ & $6.5 \pm 0.7 \mathrm{a}$ & $8.9 \pm 6.2 \mathrm{a}$ & $27.5 \pm 10.5 \mathrm{a}$ & $2.1 \pm 1.0 \mathrm{a}$ & $1.9 \pm 0.7 \mathrm{a}$ \\
\hline Control & $10.4 \pm 2.1 \mathrm{~b}$ & $30.5 \pm 6.8 \mathrm{~b}$ & $26.9 \pm 11.0 \mathrm{~b}$ & $5.1 \pm 1.0 \mathrm{~b}$ & $1.9 \pm 1.1 \mathrm{~b}$ & $7.9 \pm 7.3 \mathrm{~b}$ & $0.7 \pm 0.2 b$ & $0.7 \pm 0.5 \mathrm{~b}$ \\
\hline
\end{tabular}

${ }^{1}$ Means $( \pm \mathrm{SD}$ ) with different letters in a column for each factor are significantly different (Tukey, $\mathrm{P} \leq 0.05$ ). 
Table 3. Physical and organoleptic characteristics in jalapeño pepper fruits cultivated with monoculture and intercropping using Bokashi and vermicompost leachate (VL) as organic fertilizers.

\begin{tabular}{|c|c|c|c|c|c|}
\hline \multirow[b]{2}{*}{ Factors } & Length & Width & \multirow{2}{*}{$\begin{array}{l}\text { Fresh weight } \\
\text { (g) }\end{array}$} & \multirow{2}{*}{$\begin{array}{l}\text { Soluble solids } \\
\quad\left({ }^{\circ} \text { Brix }\right)\end{array}$} & \multirow{2}{*}{$\begin{array}{l}\text { Capsaicin } \\
\left(\mathrm{mg} \mathrm{g}^{-1}\right)\end{array}$} \\
\hline & \multicolumn{2}{|c|}{$(\mathrm{mm})$} & & & \\
\hline \multicolumn{6}{|l|}{ Culture type } \\
\hline Monoculture & $48.5 \pm 4.8 \mathrm{a}^{1}$ & $18.8 \pm 1.5 \mathrm{a}$ & $9.0 \pm 1.8 \mathrm{a}$ & $1.6 \pm 0.67 \mathrm{a}$ & $0.31 \pm 0.09 \mathrm{a}$ \\
\hline Intercropping & $46.2 \pm 5.2 \mathrm{a}$ & $18.2 \pm 1.8 \mathrm{a}$ & $8.2 \pm 2.0 \mathrm{a}$ & $1.4 \pm 0.52 \mathrm{a}$ & $0.31 \pm 0.13 \mathrm{a}$ \\
\hline \multicolumn{6}{|l|}{ Fertilization } \\
\hline Bokashi & $47.9 \pm 3.9 \mathrm{a}$ & $18.8 \pm 1.6 \mathrm{a}$ & $9.0 \pm 1.4 \mathrm{a}$ & $1.5 \pm 0.71 \mathrm{a}$ & $0.32 \pm 0.10 \mathrm{ab}$ \\
\hline Bokashi + VL & $45.4 \pm 4.7 \mathrm{a}$ & $18.8 \pm 2.1 \mathrm{a}$ & $8.5 \pm 2.4 \mathrm{a}$ & $1.8 \pm 0.44 \mathrm{a}$ & $0.36 \pm 0.10 \mathrm{a}$ \\
\hline Control & $48.6 \pm 6.3 \mathrm{a}$ & $18.0 \pm 1.2 \mathrm{a}$ & $8.2 \pm 1.8 \mathrm{a}$ & $1.2 \pm 0.41 \mathrm{a}$ & $0.25 \pm 0.12 \mathrm{~b}$ \\
\hline
\end{tabular}

${ }^{1}$ Means $( \pm \mathrm{SD})$ with different letters in the columns for each factor are significantly different (Tukey, $\mathrm{P} \leq 0.05$ ).

chanical and biological defects. The amount of soluble solids in jalapeño pepper did not vary between treatments. The concentration of capsaicin was significantly higher $(\mathrm{P} \leq 0.05)$ in Bokashi plus VL (41\%) than in the control (Table 3). The observed capsaicin values coincide with those reported by (García et al., 2006). Capsaicin is a compound of nitrogen sources, and its increase may be related to the nutritional status of the plant (Vázquez-Flota et al., 2007). Johnson and Decoteau (1996) found that the capsaicin content had a quadratic response to nitrogen fertilization. According to the results of analyses of soil and Bokashi, the contents of total $\mathrm{N}$ occur at very high levels. In addition, the activity of the -O-methyltransferase caffeic acid enzymes and synthetase capsaicinoids may be the main limiting factor for the production of capsaicinoids in in vitro cultures (Ochoa and Gómez, 1993). Additionally, the application of organic fertilizer has a positive effect on the enzyme activity (Acosta and Paolini, 2005).

The onion bulb size showed a significant difference $(\mathrm{P} \leq 0.05)$ when Bokashi was applied, with increases of 28, 69 and $269 \%$ in the polar and equatorial diameters and weight, respectively, compared to the control (Table 4). According to the Mexican Official Norm (2003), a middle size $(5.1-7.0 \mathrm{~cm})$ of onion was found. The onion presented development, coloration and brightness that were typical of the variety; therefore, it was considered a premium product. The application of organic fertilizer promoted the increase of soluble solids in onion bulb (Table 4 ); however, the values obtained were lower than those reported by Abrameto et al. (2010). The soluble solids content is important because it relates to the sweetness of the fruit, but when the concentration of organosulfur compounds is high, the sweet taste produced by sugars of the onion is not perceived (Mallor, 2008). It has been found that vermicompost increased the content of soluble solids in tomato and jalapeño pepper (Gutiérrez-Miceli et al., 2007; Oliva-Llaven et al., 2008). Pyruvic acid in onion bulbs showed no significant difference between the fertilization treatments and intercropping. However, onion bulbs had 66 and $41 \%$ more piruvic acid with Bokashi and Bocashi plus LV than did the control plants (Table 4). The concentration of pyruvic acid was within the range reported by Abrameto et al. (2010) and higher than that reported by Hamilton et al. (1998). The values of pyruvic acid in onions found in this study are higher, and the onions are thus considered spicy, possibly due to the scarcity of water during the growing period that was reflected in the water content of the bulbs, thereby increasing the concentration of sulfur compounds (Sun et al., 2006). The concentration of pyruvic acid in onion bulbs is associated with agronomic practices, such as the amount of water in the fruit and the ability of the plant to accumulate sulfur compound into cells (Raigón, 2006). 
Table 4. Physical and organoleptic characteristics in onion bulbs cultivated as monoculture and intercropping using Bokashi and vermicompost leachate (VL) as organic fertilizers.

\begin{tabular}{lcccccc}
\hline & $\begin{array}{c}\text { Polar } \\
\text { diameter }\end{array}$ & $\begin{array}{c}\text { Equatorial } \\
\text { diameter }\end{array}$ & & $\begin{array}{c}\text { Fresh } \\
\text { weight } \\
\left(\mathrm{g} \mathrm{plant}^{-1}\right)\end{array}$ & $\begin{array}{c}\text { Soluble solids } \\
\left({ }^{\circ} \text { Brix }\right)\end{array}$ & $\begin{array}{c}\text { Pyruvic } \\
\text { acid } \\
\left(\mu \mathrm{M} \mathrm{g}^{-1}\right)\end{array}$ \\
\cline { 2 - 3 } $\begin{array}{l}\text { Culture type } \\
\text { Monoculture }\end{array}$ & \multicolumn{2}{c}{$(\mathrm{mm})$} & & & & \\
$\quad$ Intercropping & $68.5 \pm 11.2 \mathrm{a}^{1}$ & $53.2 \pm 13.7 \mathrm{a}$ & $100.1 \pm 62.2 \mathrm{a}$ & $2.1 \pm 0.79 \mathrm{a}$ & $11.0 \pm 4.03 \mathrm{a}$ \\
Fertilization & $66.7 \pm 8.5 \mathrm{a}$ & $54.1 \pm 13.9 \mathrm{a}$ & $97.0 \pm 53.0 \mathrm{a}$ & $2.3 \pm 0.42 \mathrm{a}$ & $10.8 \pm 3.75 \mathrm{a}$ \\
Bokashi & & & & & $12.0 \pm 4.33 \mathrm{a}$ \\
Bokashi $+\mathrm{VL}$ & $74.1 \pm 6.9 \mathrm{a}$ & $64.9 \pm 7.8 \mathrm{a}$ & $142.6 \pm 44.8 \mathrm{a}$ & $2.7 \pm 0.41 \mathrm{a}$ & $11.2 \pm 4.23 \mathrm{a}$ \\
Control & $70.9 \pm 6.8 \mathrm{a}$ & $57.9 \pm 7.5 \mathrm{a}$ & $114.4 \pm 40.3 \mathrm{a}$ & $2.3 \pm 0.42 \mathrm{a}$ & $9.6 \pm 2.74 \mathrm{a}$ \\
\hline
\end{tabular}

${ }^{1}$ Means $( \pm \mathrm{SD})$ with different letters in the columns for each factor are significantly different (Tukey, $\left.\mathrm{P} \leq 0.05\right)$.

\section{Yield and land equivalent ratio (LER)}

The yield of onion showed highly significant differences between fertilization treatments $(\mathrm{P} \leq 0.01)$. The onion yield in monoculture was 257 and 243\% higher with Bokashi and Bokashi plus VL than in the control plants without fertilizer, whereas in intercropping, the increased yield was 194\% and 185\%, respectively (Table 5). The yield of onion with Bokashi in monoculture treatment $\left(24.5 \mathrm{t} \mathrm{ha}^{-1}\right)$ is near the national average (28.2 $\mathrm{t} \mathrm{ha}^{-1}$ ) (SAGARPA, 2010), indicating that the use of this compost is favorable to support the production of onion. In contrast, the yield of jalapeño pepper did not vary significantly between fertilization treatments, and the yield that was attained with Bokashi plus VL in monoculture (1.9 $\left.\mathrm{t} \mathrm{ha}^{-1}\right)$ was lower than the national average (12 $\left.\mathrm{t} \mathrm{ha}^{-1}\right)$ (Lujan et al., 2010). It is possible that the low yield obtained with jalapeño pepper was due to the presence of some diseases during early vegetative growth, such as cercospora leaf spot (Cercospora capsici), basal stem rot (Phytophthora spp.) and evil of the stem (Fusarium spp.). Although these diseases were controlled with the application of Bordeaux mixture, they may have influenced the early plant development.

In all fertilization treatments, jalapeño pepper and onion intercropping showed a greater the LER compared with monocultures (Table 5), indicating a more efficient use of land in intercropping. A maximum LER of 1.55 for combined yield of onion and jalapeño pepper in intercropping with the application of Bokashi was attained. This LER indicates that the area planted in monocultures would need to be $55 \%$ greater than the area planted to the intercrop for the two to produce the same combined yield (Dariush et al., 2006). Moreover, a LER higher than 1.0 indicates that the presence of positive inter-specific interference that exists in the mixture is not as intensive as the inter-specific interference that exists in the monoculture (Ahmed, 2012).

In conclusion, the fertilization with Bokashi increased the growth and weight of onion and jalapeño pepper plants. Additionally, Bokashi promoted higher diameter and weight of onion bulb, as reflected in the increase in yield. Bokashi plus Vermicompost Leachate (VL) increased capsaicin concentration in the fruit of jalapeño pepper and soluble solids in onion bulb. The Land Equivalent Ratio was higher than 1.0, indicating a more efficient land use with intercropping in comparison with the monoculture. Therefore, organic fertilization and intercropping are two agroecological management practices that favor the yield and quality of jalapeño pepper and onion with an efficient use of the land. 
Table 5. Yield and Land Equivalent Ratio (LER) in pepper and onion plants cultivated as monoculture (M) or intercropping (I) using Bokashi and vermicompost leachate (VL) as organic fertilizers.

\begin{tabular}{|c|c|c|c|c|c|c|}
\hline \multirow{2}{*}{$\begin{array}{l}\text { Organic } \\
\text { fertilizers }\end{array}$} & \multirow{2}{*}{$\begin{array}{c}\text { Culture } \\
\text { type }\end{array}$} & \multicolumn{2}{|c|}{ Yield $\left(\mathrm{t} \mathrm{ha}^{-1}\right)$} & \multicolumn{2}{|c|}{ Partial LER } & \multirow[b]{2}{*}{ LER } \\
\hline & & Onion & Pepper & Onion & Pepper & \\
\hline \multirow[t]{2}{*}{ Bokashi } & M & $24.5 \pm 9.5 \mathrm{a}^{1}$ & $1.6 \pm 0.8 \mathrm{a}$ & 0.72 & 0.83 & \\
\hline & I & $17.5 \pm 5.2 \mathrm{ab}$ & $1.3 \pm 0.4 \mathrm{a}$ & & & 1.55 \\
\hline \multirow[t]{2}{*}{ Bokashi + VL } & M & $23.5 \pm 8.4 \mathrm{a}$ & $1.9 \pm 1.1 \mathrm{a}$ & 0.72 & 0.62 & \\
\hline & I & $17.0 \pm 3.7 \mathrm{ab}$ & $1.3 \pm 1.0 \mathrm{a}$ & & & 1.34 \\
\hline \multirow[t]{2}{*}{ Control } & M & $6.9 \pm 1.4 \mathrm{~b}$ & $1.4 \pm 0.7 \mathrm{a}$ & 0.87 & 0.67 & \\
\hline & I & $6.0 \pm 0.9 \mathrm{~b}$ & $0.9 \pm 0.5 \mathrm{a}$ & & & 1.54 \\
\hline
\end{tabular}

${ }^{1}$ Means $( \pm \mathrm{SD})$ with different letters in the columns within each factor are significantly different (Tukey, $\left.\mathrm{P} \leq 0.05\right)$.

\section{Acknowledgements}

This research was supported by FORDECYTCONACYT (project no. 143303), Mexico. The authors wish to thank our anonymous referees for constructive suggestions to the manuscript.

\section{Resumen}

J.D. Álvarez-Solís, J.A. Mendoza-Núñez, N.S. León-Martínez, J. Castellanos-Albores y F.A. Gutiérrez-Miceli. 2016. Efecto de bokashi y lixiviado de vermicomposta sobre el rendimiento y la calidad de chile (Capsicum annuum) y cebolla (Allium cepa) en monocultivo y cultivos asociados. Cien. Inv. Agr. 43(2):243-252. La fertilización orgánica y la asociación de cultivos son dos prácticas de manejo agroecológico con el potencial de optimizar el uso de la tierra en la producción hortícola. El objetivo de este estudio fue evaluar el efecto de Bokashi y Bokashi adicionado con Lixiviado de Vermicomposta (LV) sobre el crecimiento, rendimiento y calidad de chile jalapeño (Capsicum annuиm L.) y cebolla (Allium cepa L.) cultivados en monocultivo y en policultivo. El experimento se realizó bajo condiciones de temporal en la comunidad Santa Rosa el Oriente, La Trinitaria, Chiapas. Se utilizó un diseño de bloques completos al azar con un arreglo de parcelas divididas con seis tratamientos y cuatro repeticiones por tratamiento. Bokashi incrementó significativamente el número de hojas y la altura de la planta en cebolla ( 37 y $62 \%$ ) y chile jalapeño (33 y 94\%) en comparación con las plantas control. En chile jalapeño y cebolla el contenido de capsaicina y sólidos solubles fueron 41 y $42 \%$ más altos con la aplicación de Bokashi adicionado con VL, respectivamente. En cebolla Bokashi incrementó 28, 69 y 269\% los diámetros polar y ecuatorial y el peso del bulbo. Con la aplicación de Bokashi el rendimiento de cebolla incrementó de 6.4 a $21 \mathrm{tha}^{-1}$. Se obtuvo una relación equivalente de tierra (RET) de 1.34 a 1.55 , indicando que el policultivo fue ventajoso sobre el monocultivo, indistintamente del tipo de fertilización. Por lo tanto, la aplicación de Bokashi y la asociación de cultivos favorecieron el rendimiento y la calidad de chile jalapeño y cebolla con un eficiente uso de la tierra.

Palabras clave: Bokashi, Capsaicina, lixiviado de Vermicomposta, Relación Equivalente de Tierra, sólidos solubles. 


\section{References}

Abrameto, M.A., C.M. Pozzo, M.I. Gil, and L.M. Molina. 2010. Analysis of methodologies for the study of composition and biochemical carbohydrate changes in harvest and postharvest onion bulbs. Phyton (Buenos Aires) 79:123132.

Acosta, Y., and J. Paolini. 2005. Activity of dehydrogenase enzyme in a calciorthids soil amended with organic residues. Agronomía Tropical 55:217-232.

Ahmed, M.S.A. 2012. Assessing the Land Equivalent Ratio (LER) of two leguminous pastures (Clitoria and Siratro) intercropping at various cultural practices and fencing at Zalingei-Western Darfur State- Sudan. ARPN Journal of Science and Technology 2:1074-1080.

Altieri, M.A., and C.I. Nicholls. 2007. Agroecological conversion of conventional production systems: theory, strategies and assessment. Ecosistemas 16: 3-12.

Altieri, M.A. 2002. Agroecology: the science of natural resource management for poor farmers in marginal environments. Agriculture, Ecosystems and Environment 93:1-24.

Álvarez-Solís, J.D., D.A. Gómez-Velasco, N.S. León-Martínez, and F.A. Gutiérrez-Miceli. 2010. Integrated management of inorganic and organic fertilizers in maize cropping. Agrociencia 44:575-586.

AOAC-Official Methods of Analysis. 1990. 15 ${ }^{\text {th }}$ Edition. Association of Official Analytical Chemists. Inc. Arlington, Virginia, USA.

Atiyeh, R.M., S. Subler, C.A. Edwards, G. Bachman, J.D. Metzger, and W. Shuster. 2000. Effects of vermicomposts and composts on plant growth in horticultural container media and soil. Pedobiologia 44:579-590.

Castro, A, C. Henríquez, and F. Bertsh. 2009. Nitrogen, phosphorus and potassium supply capacity in four organic amendments. Agronomía Costarricense 33:31-43.

Dariush, M., M. Ahad, and O. Meysam. 2006. Assessing the Land Equivalent Ratio (LER) of two corn (Zea mays L.) varieties intercropping at various nitrogen levels in Karaj, Iran. Journal of Central European Agriculture 7:359-364.

García, B.L. 2003. Plant-plant interactions in tropical agriculture. In: Vandermeer, J. (ed.) Tropical Agroecosystems. Florida: CRC Press Boca Raton. p. 12-58.

García, I., N.G. Miranda, L.R. González, and F. Nieto. 2006. Preliminary studies of the fermentation of jalapeño pepper (Capsicum annuum L.). Investigación Universitaria Multidisciplinaria $5: 36-42$

García-Gómez, R.C., L. Dendooven, and F.A. Gutiérrez-Miceli. 2008. Vermicomposting leachate (worm tea) as liquid fertilizer for maize (Zea mays L.) forage production. Asian Journal of Plant Sciences 7:360-367.

Gutiérrez-Miceli, F.A., J. Santiago, J. Montes, C. Nafate, A. Archila, M.A. Oliva, R. Rincón, and L. Dendooven. 2007. Vermicompost as a soil supplement to improve growth, yield and fruit quality of tomato (Lycopersicum esculetum). Bioresource Technology 98:2781-2786.

Hamilton, B.K., K.S. Yoo, and L.M. Pike. 1998. Changes in pungency of onions by soil type, sulphur nutrition and bulb maturity. Scientia Horticulturae 74:249-256.

Johnson, C.D., and D.R. Decoteau. 1996. Nitrogen and potassium fertility affects jalapeño pepper plant growth, pod yield, and pungency. HortScience 31:1119-1123.

Lujan, F.M., R.G.F. Acosta, P.F.J. Quiñones, M.H.R. Uribe, M.M. Berzoza, M.J.L. Aldaba, L.R. Galván, M.R. Rodríguez, and S.N. Chávez. 2010. Jalapeño pepper. Instituto Nacional de Investigaciones Forestales Agrícolas y Pecuarias. Available on line at: http://sites.securemgr.com/folder11341/ index.cfm? $\mathrm{id}=1382935 \&$ fuseaction=browse $\&$ pag eid=45 (Website accessed; April 15, 2012).

Malézieux, E., Y. Crozat, C. Dupraz, M. Laurans, D. Makowski, H. Ozier-Lafontaine, B. Rapidel, S. Tourdonnet, and M. Valantin-Morison. 2009. Mixing plant species in cropping systems: concepts, tools and models: a review. Agronomy for Sustainable Development 29:43-62.

Mallor, G.C. 2008. Main varieties of onion for spring-summer. Horticultura 205:10-14. 
Mexican Official Norm. 2002. NOM-021-RECNAT-2000. Establishing the specifications of fertility, salinity and soil classification. Studies, sampling and analysis. Secretaría de Medio Ambiente y Recursos Naturales. Available online at: http://biblioteca.semarnat.gob.mx/janium/Documentos/Ciga/libros2009/DO2280n.pdf (Website accessed: August 12, 2010).

Mexican Official Norm. 2003. NMX-FF-021-SCFI-2003. Non-industrialized food products for human consumption - bulb - onion (Allium cepa L.) Secretaría de Medio Ambiente y Recursos Naturales. Available online at: http://s3.esoft. com.mx/esofthands/include/upload_files/4/Archivos/NMX-FF-021-SCFI-2003.pdf (Website accessed: February 12, 2011).

Mexican Official Norm. 2007. NMX-FF-025-SCFI-2007. Non-industrialized food products for human consumption - fresh chilli - (Capsicum spp.) specifications [Internet]. Secretaría de Medio Ambiente y Recursos Naturales. Available online at: http://s3.esoft.com.mx/esofthands/ include/upload_files/4/Archivos/NMX-FF025-SCFI-2007.pdf (website accessed: January 25, 2011).

Ochoa, N., and J. Gómez. 1993. Activity of enzymes involved in capsaicin biosynthesis in callus tissue and fruits of chili pepper (Capsicum annuum L.). Journal of Plant Physiology 141:147-152.

Oliva-Llaven, M.A., J.L. Guzmán, B.I. Cabrera, R. Rincón, J. Montes, L. Dendooven, and M.A. Gutiérrez-Miceli. 2008. Fruit characteristics of bell peper cultivated in sheep manure vermicompost substituted soil. Journal of Plant Nutrition 31:1585-1598.

Oliva-Llaven, M.A., L. Rodríguez-Hernández, B. Ruiz-Sesma, J.D. Álvarez-Solís, L. Dendooven, and F.A. Gutiérrez-Miceli. 2010. Optimization of worm-bed leachate for culturing of tomato ( $\mathrm{Lyco}-$ persicon esculentum Mill) inoculated with Glomus fasciculatum and Pseudomonas fluorescens. Electronic Journal of Biotechnology 13:1-8.

Raigón, M.D. 2006. The level of pungency of onions. Horticultura Internacional 51:48-51.

Ramírez-Marcial, N., M. González-Espinosa, A. Camacho-Cruz, and D. Ortiz-Aguilar. 2010. For- est restoration in Lagunas de Montebello National Park, Chiapas, México. Ecological Restoration 28:354-360.

Restrepo, R.J. 2007. The $\mathrm{ABC}$ of organic agriculture and rock flour. Managua (Nicaragua): Ed. SIMAS.

SAGARPA (Secretaria de Agricultura, Ganadería, Desarrollo Rural, Pesca y Alimentación). 2010. Statistical Yearbook of Agricultural Production in Mexico. SAGARPA. Available online at: http://www.siap.gob.mx/cierre-de-la-produccion-agricola-por-cultivo/ (Website accessed: January 20, 2012).

Sinaj, S., O. Traore, and E. Frossard. 2002. Effect of compost and soil properties on the availability of compost phosphate for white clover (Trifolium repens L.). Nutrient Cycling in Agroecosystems 62:89-102.

Sun, K., L. Pike, K. Crosby, R. Jones, and D. Leskovar. 2006. Differences in onion pungency due to cultivars, growth environment, and bulb sizes. Scientia Horticulturae 10:144-149.

Teare-Ketter, C.A., and W.M. Randle. 1998. Pungency assessment in onions. In: Karcher, S.J. (ed). Tested studies for laboratory teaching. Proceedings of the 19th Workshop/Conference of the Association for Biology Laboratory Education (ABLE). p. 177-196.

van Diepeningen, A.D., O.J. de Vos, G.W. Korthals, and A.H.C. van Bruggen. 2006. Effects of organic versus conventional management on chemical and biological parameters in agricultural soils. Applied Soil Ecology 31:120-135.

Vandermeer, J.H. 1990. Intercropping. In: Carroll, C.R., J.H. Vandermeer, and P. Rosset (eds). Agroecology. New York: McGraw-Hill Publishers. p. 481-515.

Vázquez-Flota, F., M.L. Miranda-Ham, M. Monforte-González, G. Gutiérrez-Carbajal, C. Velázquez-García, and Y. Nieto-Pelayo. 2007. Biosynthesis of capsaicinoids, the pungent principle of peppers. Revista Fitotecnia Mexicana 30:353360.

Willey, R.W., and M.R. Rao. 1980. A competitive ratio for quantifying competition between intercrops. Experimental Agriculture 16:117-125. 